\title{
The study on the Financing Difficulties and Countermeasures of China's Private Enterprises in Recent Years
}

\author{
Jinxin Yang ${ }^{1}$ \\ ${ }^{1}$ Unit: University Of Dalian, Dalian 116000, China
}

\begin{abstract}
Private enterprises occupies an important position in China's economic development. They have played an important role in maintaining stable economic growth, promoting entrepreneurship, increasing employment, providing taxes, and improving people's lives. They are an important force in promoting highquality enterprises. Based on the analysis of relevant data, this paper concludes that the financing difficulties of private enterprises are caused by both themselves and the investors, and provides countermeasures from financial system reform, Build a risk prevention mechanism, information platform construction, and enterprise self-management, etc, aiming to solve the private economy Practical problems.economic development in China. Financing is an important condition for the healthy development of private enterprises, and financing has always been a major problem for the development of private.
\end{abstract}

\section{Introduce}

Private enterprises are an important driving force for China's economic development, and financing issues have always restricted the healthy development of private enterprises for a long time. Today the global economic risks are waxing, while the economic development have been restricted. The domestic economic development is facing structural adjustments, industrial upgrading, and greater pressure from the market and capital. Some private enterprises have encountered problems such as operating difficulties and single financing channels. Relevant laws and policies have been given by the government supportively, but the current financing problem has not been fundamentally resolved. Nearly $70 \%$ of enterprises in china claim that financing is extremely difficult, which is higher than that of developed countries and much higher than that of emerging industrial countries in Asia.

\section{The current state of private economic financing}

\subsection{The growth rate of private enterprise loans is still lower than that of state-owned enterprises}

State-owned enterprises and private enterprises are two important components of the Chinese economy. From 2011 to 2017, the year-on-year growth rate of loans to state-owned holding companies continued to rise, with $8 \%$ rising to $20.8 \%$; The $28.5 \%$ at the end of 2011 dropped to $3.1 \%$ at the end of 2016 , and it rose to $7.1 \%$ in 2017 . In
2018, the growth rate of loans to state-controlled enterprises was $11.8 \%$, while the growth rate of loans to privately-held enterprises was around $8 \%$. It can be seen that the growth gap between the two is constantly narrowing, but in comparison, privately held corporate loans are still in a weak position.

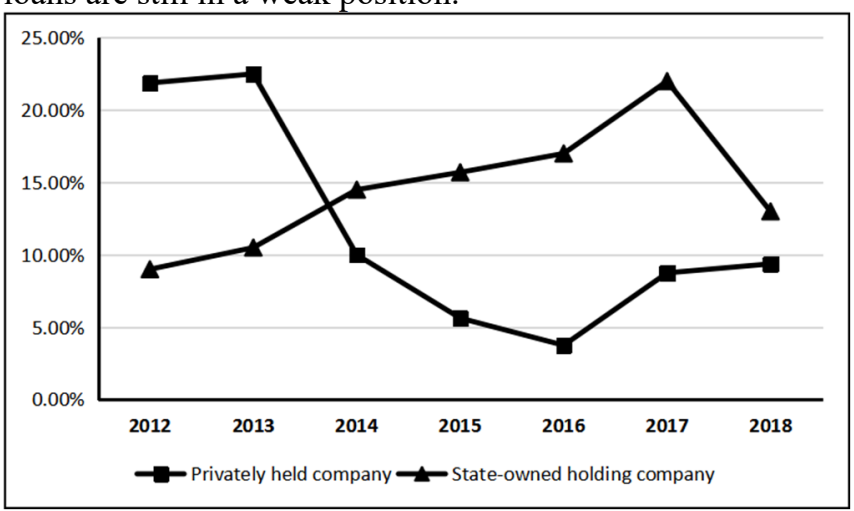

Figure 1: 2012-2018 year-on-year growth rate of corporate loans

\subsection{Private letter corporate credit Securities financing continues to decrease}

From the perspective of the issuance of credit bonds, state-owned enterprises have always been in an advantageous position. In 2010, the credit bonds issued by state-owned enterprises were 40.2 times that of private enterprises. In 2017, the credit bonds issued by stateowned enterprises were 6.9 times that of private enterprises. Affected by international economic and trade frictions and insufficient domestic consumption capacity,

e-mail: yang1332310085@163.com 
in 2018, the amount of credit bonds issued by state-owned enterprises rose to 15 times that of private enterprises. The capital market fluctuated in May 2019, and people began to show risk aversion. The financing environment for private companies further deteriorated, from $6.5 \%$ in April 2019 to 3.7\% in September 2019 [1]. From the perspective of net financing, since 2017, the overall scale of credit debt net financing has shrunk, and the net financing of private enterprises has fallen to a negative number. Although the government actively supports the issuance of credit bonds by private companies and has introduced related policies, the scale of bond financing by private companies has not expanded, but has been shrinking. In 2017, the financing amount of private enterprises was 618.191 billion yuan, down 36\% year-onyear. In 2018, the net financing amount of private enterprises has been reduced to 7.188 billion yuan, only $1.1 \%$ of 2017. According to pricewaterhousecoopers analysis, there were 105 ipos on the Shanghai and Shenzhen stock markets in 2018, a 76\% decrease compared to 436 in 2017; the financing scale was 138.6 billion yuan, which was far lower than the 230.4 billion yuan in $2017,40 \%$ reduction [2]. Looking at the stock of bonds, the stock of Chinese corporate credit bonds in September 2019 The balance is 41.29 trillion yuan, the stock of state-owned enterprises' credit bonds is 26.91 trillion yuan, and the stock of private enterprises' credit bonds is 2.73 trillion yuan, with private enterprises accounting for only $6.6 \%[3]$.

\section{The analysis of the Causes of Difficulty and Expensive Financing of Private Enterprises}

\subsection{From the perspective of investors}

China's financial system is still dominated by banks, and it is difficult to meet the financing needs of private enterprises solely by banking services. At present, the development of China's banking service industry is lagging behind, and private enterprises and state-owned enterprises are treated differently. It is good at providing single and systematic services to state-owned enterprises, but cannot provide personalized and innovative services to private enterprises. The backwardness of banking services has made it increasingly difficult for private companies to obtain loans from formal banks, which has enabled the development of informal financial services. On the one hand, private companies have obtained funds for development through informal financial services. On the other hand, Informal finance also brings huge risks to the development of private enterprises. The loan interest rate of informal financial institutions is much higher than that of formal financial institutions. Once an enterprise has problems with its efficiency, the high fees of informal financial institutions may also cause the enterprise to go bankrupt. In addition, the continuous strengthening of national financial supervision The governance of financial institutions also makes it more difficult for private companies to finance.
The failure of the government's financial policies is attribute to the financing implement of difficulties of the private economy. The assessment and supervision of government financial institutions are so strict that restricting the active development of private economic and financial services. The financial regulatory authorities have over-strict regulations on the credit risk of bank loans to smes. They believe that lending to state-owned enterprises and private enterprises will consume manpower and material resources. Meanwhile, the risk of lending to private enterprises is much bigger than to stateowned enterprises if something wrong, they will be subject to regulatory authorities. Out of the mentality of seeking stability, financial institutions have imposed additional restrictions on loans to private enterprises. In addition, many financing policy settings tend to be idealized and difficult to implement [4].

The speed of economic development runs slowly, and financial institutions have low willingness to issue loans. Chasing profits is the fundamental goal of financial institutions. Due to the slowdown of global economic development, frequent economic and trade frictions between China and other countries, increased international financial risks, and domestic economic transformation become more difficult. The increasing operating risks of private enterprises have caused financial institutions to reduce loans to private enterprises out of their own considerations.

\subsection{From the perspective of the enterprise itself}

credit is a prerequisite and necessary condition for the establishment of a credit relationship. Private enterprises lack their own credit. Not only are they not protected by the government like state-owned enterprises, but the assets pledged by their own guarantee are insufficient to meet their needs. Wind data shows that the survey in April 2019 pointed out that the non-performing loan ratio of rural commercial banks was about $4 \%$, and that of urban commercial banks reached 2.3\%. Before October 2019, the stock of private enterprise bonds with a credit rating of AAA was 550 billion yuan, with a default amount of up to 31 billion yuan, and a default rate of $5.70 \%$; the credit default rate of private enterprises with a credit rating of $\mathrm{AA}+$ was as high as $21.79 \%$. The default rate of credit bonds of private enterprises with a credit rating of $\mathrm{AA}$ is as high as $49.7 \%$. The balance of non-compliant bonds of private enterprises was 155.59 billion yuan, and the default rate was $8.58 \%$. In contrast, the balance of default bonds of state-owned enterprises was 35.4 billion yuan, and the default rate was only $0.07 \%$.

Private enterprises have deviations in their understanding of financing policies and financial tools, and their financing concepts are backward. The unfair treatment encountered by private in financing, on the one hand, my country's long-standing economic system factors, favors state-owned enterprises. Private enterprises are mostly small and medium-sized enterprises, their own scale is small, the asset quality is not high, and they are not favored by external funds. 
Major financial providers tend to invest in various large state-owned enterprises. Some banks and lending institutions believe that state-owned enterprises have the state as a guarantee and are more willing to lend to stateowned enterprises, while for private enterprises, they adopt a strict review mode, requiring certain assets as guarantees or third-party guarantees before they are willing to lend. On the other hand, some companies lack an understanding of financial policies and financial tools, and take an evasive attitude towards formal financing channels, believing that formal financing will have an unreasonable impact on companies, and some companies even create false financial accounts to defraud them. The loans of financial institutions have not only prevented them from enjoying the benefits brought by the national financing policy, but also made it difficult for themselves to develop, and finally faced bankruptcy.

The development environment for private enterprises has deteriorated. At present, the financing methods of private enterprises in china are mainly internal financing. The internal financing methods mainly include management investment, enterprise's own accumulation, personal borrowing, etc. It is inevitable that such financing methods will have small capital scale, lack of stability and Limitations of persistence. It may be able to meet the short-term financing needs of enterprises, but in the long run it cannot solve the problem of financial support for private enterprises. The external financing channels of private enterprises mainly include bank loans, equity financing, bond financing, etc. At present, due to the limitations of the enterprise itself and the imperfection of the external financial market, the external financing for enterprises is less. Lack of long-term investment funds, private enterprises often have sufficient short-term credit funds, and it is difficult to find support for long-term investment funds, which is not conducive to the long-term development of private enterprises in the market environment.

\section{Countermeasures to Solve the Financial Difficulties of Private Enterprises}

\subsection{Intensify reform of the financial system and improve the financial market system}

Unequal treatment of private companies, single financing channels for private companies, and backward banking services are important factors restricting private companies' financing. First, we must build a multi-level banking system and credit system with differentiated services. Guiding various financial institutions to clarify the target of financing services, increase financial support for private enterprises, exploring multi-level supervision methods, unified services increasing the tolerance of commercial banks to non-performing loans, and increase the willingness to lend. Secondly, we must accelerate the construction of a multi-level capital market, To meet the diversified investment needs of enterprises of different types and stages of development, improving the credit bond issuance system and the equity credit system, and reduce the dependence of private enterprises on bank loans. Finally, it is necessary to strengthen the guiding role of LPR in market loan interest rates, to truly reflect the changes in my country's social financing, and to stabilize social expectations.

\subsection{Establishing to mechanism for information exchange among the government, enterprises, and financial institutions}

Build an information publishing network and establish a corporate information database. The government and financial institutions will publish relevant economic policies and credit products on the platform in a timely manner. Enterprises can apply for relevant financial needs on the platform according to their own circumstances. Financial institutions are based on the structured corporate information Library, comprehensively evaluate all aspects of the enterprise, and give reasonable results. In addition, it is necessary to publish a list of some high-quality private enterprises and small and medium-sized enterprises on the information platform based on a multifaceted investigation of corporate information, expanding the information sources of financial institutions, stimulating the vitality of the financial market, strengthen competition among various financial institutions, and to provide a private Provide good loan services for corporate financing. It will help private enterprises have more choice and voice in the financial market, and help the whole society to form a good atmosphere that values its own credit.

\subsection{Improving the risk prevention mechanism and violation punishment system to improve the financial market environment}

Government departments must take active actions to deal with non-performing loans and mortgages of private enterprises quickly. This can not only purify the industry atmosphere in private enterprises, but also enhance the confidence of financial institutions. Financial institutions can more actively carry out various types of financial services. business. It is necessary to improve various financing policies to reverse the difficulty of handling non-performing loans of private enterprises. Improve the judicial protection mechanism for creditors, take strict punitive measures for companies that borrow too much and cannot effectively use capital, curb speculation in the financial market, and improve the financial market environment.

\subsection{Private enterprises must continuously improve their viability and cherish their credit qualifications}

An important reason for the financing difficulties of private enterprises is that the enterprises themselves are poorly managed and do not pay attention to their own credit qualifications. Private enterprises should rely on 
technological innovation, service innovation, and management innovation to continuously improve their competitiveness in the market to ensure that their own benefits are good. At the same time, enterprises should not think that more financing is a good thing when financing, but should combine their actual needs. To consider and get reasonable financing needs. In the past year, the default rate of Chinese companies has been rising, and the number of companies in default has been increasing. Private enterprises should correct their attitudes, realize the importance of their own credit, and regard good credit as one of the advantages of financing.

\section{Conclusions}

At present, China's economic development is inseparable from the huge contribution of private enterprises, which are increasingly becoming an indispensable and important force for China's economic development. It can be seen that there are many reasons for the financing difficulties of private enterprises, including the economic downturn in the general environment, the strict control of financing by investors, and the defects of private enterprises themselves. Efforts should be made in various aspects, including financial system reform, policy coordination and cooperation, policy concept publicity, sound risk prevention mechanisms, and enhancement of their own capabilities to strive to improve a good environment for private enterprises' financing.

\section{References}

1. People's Bank of China.(2019) Corporate Finance Report .http://www.pbc.gov.cn/.

2. Q.H. Wang.(2019) In 2018, the IPO meeting rate of 119 tickets dropped to $59 \%$.Seek truth from facts, $17: 8-12$

3. Y.L. Gao.(2019)Report on the Development of China's Private Economy.No.16,2018-2019. China Business United Press,Beijing.p27.

4. Y. Meng.(2020)The solution to the problem of financing difficulties .Journal of Tianjin Normal University,.02:40-50 